\title{
ASPEK-ASPEK SOSIAL BUDAYA DALAM KERANGKA UPAYA PEMBERDAYAAN MASYARAKAT NELAYAN DI INDONESIA
}

\author{
Tjahjo Tri Hartono dan Zahri Nasution*)
}

\begin{abstract}
ABSTRAK
Penelitian dengan tujuan menganalisis peran dan pengaruh aspek-aspek sosial budaya masyarakat nelayan terhadap upaya pemberdayaan masyarakat nelayan telah dilakukan pada tahun 2003. Lima dimensi kehidupan, yaitu kesehatan masyarakat, ekonomi, hukum adat, politik, dan tingkah laku beserta faktor-faktor penyusunnya digunakan sebagai indikator kondisi aspekaspek sosial budaya masyarakat nelayan yang diteliti. Deskripsi atas kondisi sosial budaya yang diperoleh dikuantitatifkan berdasarkan justifikasi kepakaran (expert judgement) ke dalam nilainilai kategorik 1, 2 dan 3, yang masing-masing memiliki arti tidak baik, cukup baik dan baik dalam konteks mendukung upaya pemberdayaan masyarakat nelayan. Adapun peran dan pengaruh aspek sosial budaya dalam mendukung upaya pemberdayaan dianalisis berturut-turut dengan teknik analisis Multi Dimensional Scaling (MDS Analysis) dan analisis leverage. Dari seluruh masyarakat nelayan di 8 kabupaten lokasi penelitian, hasil analisis MDS dengan skala nilai $0-100$, menunjukkan besarnya peran relatif setiap dimensi sosial budaya yang terkait dengan upaya pemberdayaan masyarakat nelayan adalah: dimensi hukum adat sebesar 31,87 , dimensi ekonomi sebesar 44,63 , dimensi kesehatan masyarakat sebesar 52,82 , dimensi politik sebesar 69,05 dan dimensi tingkah laku sebesar 75,98. Nampak dimensi tingkah laku manusia memiliki pengaruh yang paling besar dalam pembentukan kondisi sosial budaya masyarakat nelayan dan upaya pemberdayaannya.
\end{abstract}

\section{ABSTRACT: Socio-culture aspects on the empowerment of fishers society in Indonesia. By: Tjahjo Tri Hartono and Zahri Nasution}

Research with an aim to asses the role and impact of socio-cultural aspects on empowerment of fisherman society has been conducted in 2003 . Five dimensions that are health of society, economic, customary law, political, and human behaviour as well as their compiler factors was used as an indicator of socio-cultural aspect conditions of fisher societies. Description of those socio-culture aspects was obtained by expert judgement. By which the values were categorized into 1, 2 and 3, which respectively means bad, good enough and good in supporting the empowerment of fisherman society effort. The role and influence of socio-cultural conditions in supporting the fisherman empowerment effort were analysed by using Multi Dimensional Scaling analysis (MDS Analysis) and leverage analysis, respectively. Analysis result of MDS shown by a scale of 0 to 100 indicated that health dimension equal to 52.82, economic 44.63, customary law 31.87, politic 69,05 and human behaviour 75.98. While, leverage analysis result revealed that human behaviour play an important role on the existence of the fisherman socio-cultural and their empowerment.

\section{KEYWORDS: fisherman socio-culture, society empowerment, multi dimensional analysis}

\section{PENDAHULUAN}

Pembangunan merupakan suatu proses perubahan di segala bidang kehidupan yang dilakukan berdasarkan suatu rencana tertentu, dengan sengaja, dan memang dikehendaki, baik oleh pemerintah yang menjadi pelopor pembangunan maupun masyarakat (Soekanto, 2003). Pada saat ini, paradigma pembangunan berorientasi pada pemberdayaan masyarakat. Dalam paradigma ini harus disadari pentingnya upaya meningkatkan kapasitas kemandirian dan kekuatan internal masyarakat yang dapat ditempuh melalui kesanggupan melakukan kontrol internal atas sumberdaya materi dan non materi yang penting melalui redistribusi modal atau kepemilikan (Hikmat, 2001).

Pengertian tersebut menunjukkan bahwa dukungan kondisi sosial budaya masyarakat merupakan salah satu faktor penting untuk mencapai keberhasilan pelaksanaan program pemberdayaan sosial dan ekonomi. Cernea (1988) juga mengemukakan bahwa pada setiap tahap pembangunan, yaitu mulai dari identifikasi program, persiapan, penilaian, pelaksanaan hingga tahap evaluasi, memerlukan sumbangan konkret berupa

\footnotetext{
"Peneliti pada Pusat Riset Pengolahan Produk dan Sosial Ekonomi Kelautan dan Perikanan
} 
informasi, analisis dan prediksi tentang aspek sosial budaya masyarakat yang bersangkutan dengan pelaksanaan pembangunan

Sementara itu, ketersediaan hasil kajian terhadap peranan kondisi sosial budaya terhadap upaya pemberdayaan masyarakat nelayan masih menjadi permasalahan menonjol saat ini dalam pembangunan di sektor kelautan dan perikanan di Indonesia, terutama yang berbasis pada pemberdayaan masyarakat nelayan. Permasalahan yang sama adalah belum banyaknya kajian terhadap berbagai aspek kehidupan yang memiliki pengaruh besar dalam menciptakan kondisi sosial budaya tersebut.

Penelitian ini dilaksanakan dengan tujuan mengkaji besarnya peranan kondisi sosial budaya terhadap pemberdayaan masyarakat nelayan berikut pengaruh dari berbagai aspek kehidupan yang membentuk kondisi sosial budaya tersebut. Hasil penelitian diharapkan menjadi salah satu sumber bahan dan informasi yang diperlukan bagi pembangunan di sektor kelautan dan perikanan di Indonesia, terutama yang berbasis pada pemberdayaan masyarakat nelayan.

\section{METODE}

\section{Pendekatan dan Lingkup Penelitian}

Kondisi sosial budaya suatu masyarakat terbentuk dari pola tingkah laku masyarakat di berbagai aspek kehidupan. Dikaitkan dengan pengertian pemberdayaan masyarakat, maka lima aspek kehidupan yaitu kesehatan masyarakat, ekonomi, hukum adat, politik, dan tingkah laku manusia perlu dikaji (Lampiran 1; Nasution et al., 2004). Pola tingkah laku masyarakat di bidang kesehatan terkait dengan kualitas sumberdaya manusia dari sisi kecukupan gizi. Aspek ekonomi memerlukan bahan komparatif mengenai sikap terhadap kerja, kekayaan maupun sistem gotong royong. Aspek hukum adat diperlukan karena merupakan aturan-aturan yang timbul dan hidup langsung dari masalah-masalah perdata yang berasal dari aktivitas masyarakat. Aspek politik diperlukan untuk menyelami masalah konflik, kekuasaan dan wewenang serta proses pengambilan keputusan yang terjadi di masyarakat. Sementara aspek tingkah laku manusia digunakan untuk menjelaskan fenomena individu yang timbul di luar norma atau aturan-aturan yang terbentuk di suatu masyarakat.

Kelima aspek (dimensi) ini akan dapat menggambarkan tentang pola tingkah laku masyarakat dan individu-individu anggota masyarakat, sistem kehidupan masyarakat serta kekuasaan dan wewenang. Gambaran tentang hal-hal tersebut akan berperan penting sebagai informasi sosial budaya dalam upaya menunjang keberhasilan kegiatan pemberdayaan masyarakat nelayan di suatu daerah.

Penelitian ini bersifat studi kasus, sehingga kesimpulan yang dihasilkan terbatas pada komunitas yang diteliti. Untuk lingkup kehidupan sosial yang lebih luas, kesimpulan tersebut hanya berlaku sebagai proposisi hipotetis.

\section{Lokasi Penelitian}

Pemilihan lokasi penelitian dilakukan secara sengaja berdasarkan kriteria tertentu. Di tingkat propinsi, penetapan berdasarkan pada perbedaan wilayah penangkapan untuk nelayan perikanan laut dan intensitas penangkapan untuk nelayan perikanan perairan pedalaman. Propinsi Sumatera Utara merupakan contoh masyarakat nelayan di perairan laut wilayah Pantai Timur Sumatera, kemudian Propinsi Jawa Barat, Jawa Tengah dan Jawa Timur merupakan contoh masyarakat nelayan di perairan laut wilayah Pantai Utara Jawa. Propinsi Sulawesi Selatan dan Nusa Tenggara Timur ditetapkan sebagai contoh masyarakat nelayan di perairan laut wilayah Timur Indonesia. Propinsi Sumatera Selatan ditetapkan sebagai contoh masyarakat nelayan di wilayah perairan tawar (ekologi sungai dan rawa) dengan kegiatan penangkapan ikan perairan tawar intensif dan Propinsi Riau untuk masyarakat nelayan di wilayah perairan tawar dengan tipe perairan dan ekologi yang sama, namun dengan kegiatan penangkapan ikan perairan tawar tidak intensif.

Kemudian dari setiap propinsi dipilih lokasi tingkat kabupaten/kota. Di tingkat wilayah administrasi ini, penetapan berdasarkan pada kabupaten/kota yang memiliki potensi perikanan tangkap cukup signifikan bagi propinsi terpilih. Informasi tersebut diperoleh melalui cara konsultasi dan diskusi dengan Dinas Kelautan dan Perikanan Propinsi

\section{Penetapan Unit Analisis}

Unit analisis penelitian adalah masyarakat nelayan di suatu desa atau komunitas. Secara kesatuan unitunit analisis diasumsikan dapat menggambarkan suatu kesatuan kondisi sosial budaya berbagai masyarakat nelayan di Indonesia. Oleh karena itu, penetapan unit analisis penelitian dilakukan melalui teknik purposive sampling, dengan kriteria berdasarkan potensi perikanan tangkap yang cukup signifikan bagi kabupaten/kota terpilih. Informasi tentang hal tersebut diperoleh dari konsultasi dan diskusi dengan Dinas Perikanan dan Kelautan Kabupaten/Kota terpilih. 


\section{Penetapan Informan}

Informan pertama adalah tokoh masyarakat Penetapannya dilakukan secara sengaja (purposif) melalui informasi yang diperoleh dari Dinas Perikanan dan Kelautan terpilih. Untuk informan selanjutnya, baik tokoh masyarakat dan atau nelayan digunakan metode snowball. Metode snowball seperti yang dikemukakan Wahyono, et al. (2001) adalah metode penetapan responden berikutnya yang didasarkan dari informasi responden sebelumnya yang diwawancarai. Melalui metode ini peneliti tidak menemui banyak kesulitan untuk mendapatkan dan menentukan responden yang akan diwawancarai dan sesuai dengan spesifikasi responden yang diinginkan oleh peneliti.

Kriteria informan adalah nelayan yang melaksanakan usaha penangkapan ikan minimal berpengalaman dan telah berdomisili selama 10 (sepuluh) tahun. Nilai 10 tahun dianggap memadai untuk memahami usaha yang dilaksanakannya dan juga telah memahami keadaan sosial budaya masyarakat secara baik dan menyeluruh. Hal ini berdasarkan pertimbangan bahwa jika seseorang telah menjalani usaha penangkapan ikan dan berdiam pada suatu komunitas selama 10 tahun maka nelayan tersebut umumnya telah menguasai teknologi penangkapan dan menjadi bagian komunitas di mana ia tinggal.

Informan nelayan laut diklasifikasi menurut statusnya yaitu juragan darat, juragan laut dan pendega/ABK (Anak Buah Kapal). Juragan darat adalah mereka yang memiliki kapal, alat penangkap ikan dan biaya operasional ke laut tetapi tidak turut serta melaksanakan penangkapan ikan kelaut. Juragan laut adalah mereka yang memiliki kapal, alat penangkap ikan, biaya operasional ke laut dan turut serta melaksanakan penangkapan ikan ke laut. Pendega atau ABK adalah mereka yang melaksanakan operasional penangkapan ikan dengan berbagai tingkatannya.

Informan masyarakat nelayan perairan umum diklasifikasi menurut curahan waktu yang mereka laksanakan dalam usaha penangkapan ikan yang dimodifikasi dari pendapat yang dikemukakan oleh Welcomme (1985) yaitu nelayan penuh (full time fishers) dan nelayan sambilan (part time fishers). Nelayan penuh adalah mereka yang mencurahkan waktunya lebih dari 8 bulan dalam setahun untuk melaksanakan usaha penangkapan ikan. Nelayan sambilan adalah mereka yang mencurahkan waktunya kurang dari 6 bulan dalam setahun untuk melaksanakan usaha penangkapan ikan. Nelayan perairan umum yang dipilih sebagai responden adalah nelayan penuh yang bekerja secara individu (perorangan).

\section{Metode Pengumpulan Data}

Pengumpulan data dilakukan melalui pengumpulan fakta mengenai kejadian dan gejala masyarakat dan kebudayaan untuk pengolahan secara ilmiah (Koentjaraningrat, 1990). Pengumpulan fakta menggunakan berbagai metode yaitu metode mengobservasi, mencatat, dan melukiskan fakta yang terjadi dalam masyarakat. Pengamatan terhadap fakta-fakta yang mencerminkan aspek sosial budaya bertujuan untuk mengenali kondisi perumahan dan lingkungan perumahan atau kampung nelayan dan melihat langsung aktivitas kenelayanan yang dilakukan oleh masyarakat nelayan. Data yang dikumpulkan merupakan informasi partisipatif sehingga pengumpulan data dilakukan dengan teknik Participatory Rural Appraisal (PRA)

\section{Metode Analisis Data}

Data hasil wawancara dalam bentuk kuesioner (Nasution et al., 2004) dan catatan lapangan yang merupakan field notes diolah secara deskriptif melalui pernyataan-pernyataan deskriptif. Hasil olahan data tersebut kemudian dikaji dengan konsep-konsep dan teori-teori dalam sosiologi dan antropologi. Fokus kajian terutama terkait dengan perspektif informan tentang masyarakat, sistem dalam kehidupan masyarakat, individu-individu anggota masyarakat serta kekuasaan dan wewenang (Berry, 2003). Kajian ditujukan untuk mentabulasi data kondisi sosial budaya masyarakat nelayan dalam bentuk faktorfaktor dalam nilai-nilai kategorik 1,2, dan 3, sesuai dengan batasan atau pengertian setiap faktor aspekaspek sosial budaya dalam kaitannya dengan upaya pemberdayaan masyarakat nelayan (Lampiran 2; Nasution et al., 2004). Hasil tabulasi tersebut merupakan bahan uji statistik yang hasilnya adalah peran setiap dimensi terhadap indikator kondisi sosial budaya serta dimensi yang berpengaruh terhadap kondisi sosial budaya masyarakat nelayan.

Uji statistik yang digunakan berdasarkan pada teknik analisis "Multi Dimensional Scaling" (MDS). Pengujian dilakukan dengan memodifikasi piranti lunak program RAPFISH (Rapid Appraisal for Fisheries) agar sesuai dengan struktur data penelitian. Uji statistik ini dipilih agar satuan ukuran dimensi sosial budaya yang beragam dapat disederhanakan ke dalam satu ukuran skala, dengan kisaran nilai antara $0-100 \%$. Nilai $0 \%$ atau tidak baik mengindikasikan tidak adanya peran sama sekali dari faktor-faktor suatu dimensi sosial budaya yang dikaji dalam mendukung upaya pemberdayaan masyarakat nelayan. Sedangkan nilai $100 \%$ mengindikasikan seluruh kondisi faktor-faktor suatu dimensi sosial budaya berperan dalam mendukung upaya pemberdayaan 
masyarakat nelayan. Dimensi dan faktor yang berpengaruh terhadap kondisi sosial budaya masyarakat nelayan yang diteliti diketahui dari hasil kajian lanjut uji MDS yaitu uji "leverage" (leverage analysis).

\section{Keterandalan Data}

Validitas data diuji melalui Keterandalan (reliabilitas) faktor-faktor sebagai penjelas indikator kondisi sosial budaya dalam kaitannya dengan pemberdayaan masyarakat nelayan diketahui berdasarkan hasil pengujian ordinasi nilai-nilai faktor per dimensi atau nilai-nilai faktor untuk keseluruhan dimensi (indikator kondisi) pada analisis Monte Carlo (Pitcher \& Preikshot, 2001).

Dari hasil analisis Monte Carlo dapat diketahui sejauh mana aspek ketidak-pastian dan anomali dari faktor yang dianalisis pada setiap dimensi dapat ditolerir. Anomali dari faktor yang dianalisis adalah apabila sebaran dari nilai hasil analisis Monte Carlo (iterasi 20 kali) berada di luar kisaran normal yang ditunjukkan oleh nilai pembatas (anchors) yang diberikan (Pitcher \& Preikshot, 2001).

Sementara itu yang dimaksud dengan ketidakpastian dari faktor yang dianalisis adalah posisi relatif antar setiap nilai faktor hasil iterasi. Kecenderungan nilai iterasi yang semakin mengelompok menunjukkan bahwa faktor-faktor tersebut semakin homogen atau baik dalam fungsinya sebagai penjelas indikator kondisi. Apabila kecenderungan nilai iterasi semakin menyebar; atau berada di luar ordinasi maka berarti bahwa ada faktor yang kurang atau tidak sesuai (tidak reliabel) untuk digunakan sebagai penjelas suatu dimensi. Besaran ketidak-pastian secara relatif juga dapat ditunjukkan oleh jarak kelompok nilai iterasi faktor-faktor dengan sumbu horizontal (sumbu skala good-bad). Semakin jauh (baik ke arah positif ataupun negatif) menunjukkan adanya faktor-faktor lain yang pada prinsipnya belum disertakan di dalam menunjukkan dimensi atau indikator kondisi yang bersangkutan.

\section{HASIL DAN BAHASAN}

\section{Aspek Sosial Budaya dan Pemberdayaan Masyarakat Nelayan}

Tabulasi data deskriptif mengenai kondisi aspekaspek sosial budaya masyarakat nelayan yang diteliti memberikan gambaran suatu ciri-ciri umum dari faktorfaktor di setiap dimensi. Ciri-ciri umum adalah suatu fakta (dari faktor) yang terjadi atau berlaku pada masyarakat nelayan di seluruh wilayah yang diteliti, yang secara sistematis dapat dianalisis dengan konsep-konsep sosiologi dan atau antropologi (Koentjaraningrat, 1990).

Lebih lanjut, ciri-ciri umum dikelompokkan sekaligus diberi nilai kategorik. Pengelompokkan ciriciri umum ini didasari pada sifat ciri-ciri umum tersebut yang dikaitkan dengan upaya pemberdayaan masyarakat nelayan (Lampiran 1).

Tabel 1. Skor indikator sosial budaya masyarakat nelayan di delapan kabupaten di Indonesia, 2003

Table 1. The scoring of fishers socio-culture indicator in eight regencies, in Indonesia, 2003

\begin{tabular}{|c|c|c|c|c|c|c|c|c|c|}
\hline \multirow{2}{*}{ No. } & \multirow{2}{*}{$\begin{array}{c}\text { Dimensi/ } \\
\text { Faktor kondisi sosial budaya/ } \\
\text { The dimension/Factors of } \\
\text { socio culture conditions }\end{array}$} & \multicolumn{8}{|c|}{ Kabupaten/Kota/Regencies } \\
\hline & & $A$ & B & C & D & $E$ & $F$ & G & $\mathrm{H}$ \\
\hline$A$ & KESEHATAN MASYARAKAT/HE & $A L T H$ & $F S C$ & ETY & & & & & \\
\hline 1 & $\begin{array}{l}\text { Pendapat masyarakat nelayan } \\
\text { tentang hidup sehat/ } \\
\text { The fishers society opinion } \\
\text { about a healthy life }\end{array}$ & 2.5 & 2.5 & 2.0 & 1.5 & 1.5 & 3.0 & 1.5 & 2.5 \\
\hline 2 & $\begin{array}{l}\text { Pendapat masyarakat nelayan } \\
\text { tentang sakit/ } \\
\text { The fishers society opinion } \\
\text { about sick }\end{array}$ & 2.0 & 2.0 & 2.0 & 1.5 & 1.5 & 1.5 & 2.5 & 2.5 \\
\hline 3 & $\begin{array}{l}\text { Sikap penduduk/masyarakat } \\
\text { nelayan terhadap dukun/ } \\
\text { The attitude of fishers society } \\
\text { to soothsayer existences }\end{array}$ & 2.0 & 1.5 & 2.0 & 3.0 & 3.0 & 2.5 & $2: 0$ & 1.5 \\
\hline
\end{tabular}


Tabel 1. Skor indikator sosial budaya masyarakat nelayan di delapan kabupaten di Indonesia, 2003 (lanjutan) Table 1. The scoring of fishers socio-culture indicator in eight regencies in Indonesia, 2003 (continued)

\begin{tabular}{|c|c|c|c|c|c|c|c|c|c|}
\hline \multirow{2}{*}{ No. } & \multirow{2}{*}{$\begin{array}{l}\quad \text { Dimensi/ } \\
\text { Faktor kondisi sosial budaya/ } \\
\text { The dimension/Factors of } \\
\text { socio culture conditions }\end{array}$} & \multicolumn{8}{|c|}{ Kabupaten/Kota/Regencies } \\
\hline & & A & B & C & D & $\mathbf{E}$ & $F$ & G & $\mathrm{H}$ \\
\hline 4 & $\begin{array}{l}\text { Sikap penduduk/nelayan } \\
\text { terhadap obat-obatan } \\
\text { tradisional/ } \\
\text { The attitude of fishers society } \\
\text { to traditional medicine }\end{array}$ & 2.0 & 2.5 & 2.0 & 2.5 & 2.5 & 3.0 & 3.0 & 3.0 \\
\hline 5 & $\begin{array}{l}\text { Kebiasaan dan pantangan } \\
\text { makan bagi masyarakat } \\
\text { nelayan/ } \\
\text { The eat behaviour and } \\
\text { abstention of fishers society }\end{array}$ & 2.0 & 2.0 & 2.0 & 3.0 & 2.0 & 2.0 & 2.0 & 2.0 \\
\hline B & EKONOMI/ECONOMICS & & & & & & & & \\
\hline 1 & $\begin{array}{l}\text { Pengaruh sistem } \\
\text { kemasyarakatan terhadap } \\
\text { aktivitas kehidupan ekonomi/ } \\
\text { The influence of social system } \\
\text { to the economic activities of } \\
\text { fishers }\end{array}$ & 1.0 & 1.0 & 1.0 & 1.0 & 1.0 & 1.0 & 1.0 & 2.5 \\
\hline 2 & $\begin{array}{l}\text { Cara berpikir, pandangan dan } \\
\text { sikap warga terhadap aktivitas } \\
\text { kehidupan ekonominyal } \\
\text { The way of thinking, view and } \\
\text { attitude of fishers to their } \\
\text { economic activities }\end{array}$ & 1.0 & 2.0 & 2.0 & 1.0 & 2.0 & 1.5 & 1.0 & 2.0 \\
\hline 3 & $\begin{array}{l}\text { Sikap hidup warga masyarakat } \\
\text { terhadap kekuatan, proses dan } \\
\text { hukum-hukum ekonomi yang } \\
\text { berlaku dalam kehidupan } \\
\text { ekonominyal } \\
\text { The living attitude of society to } \\
\text { economic power, process, and } \\
\text { laws that applies to their } \\
\text { economic activities }\end{array}$ & 1.0 & 2.0 & 2.0 & 2.0 & 2.0 & 1.5 & 1.0 & 2.0 \\
\hline 4 & $\begin{array}{l}\text { Sikap warga masyarakat } \\
\text { terhadap kerja (orientasi } \\
\text { budaya)/ } \\
\text { The working attitude of } \\
\text { society(culture orientation) }\end{array}$ & 2.5 & 2.5 & 3.0 & 2.5 & 2.0 & 1.5 & 2.5 & 2.0 \\
\hline 5 & $\begin{array}{l}\text { Sikap warga masyarakat } \\
\text { terhadap kekayaan/ } \\
\text { The society attitude to } \\
\text { properties }\end{array}$ & 2.5 & 2.5 & 2.5 & 1.0 & 1.0 & 3.0 & 3.0 & 3.0 \\
\hline
\end{tabular}


Tabel 1. Skor indikator sosial budaya masyarakat nelayan di delapan kabupaten di Indonesia, 2003 (lanjutan)

Table 1. The scoring of fishers socio-culture indicator in eight regencies in Indonesia, 2003 (continued)

\begin{tabular}{|c|c|c|c|c|c|c|c|c|c|}
\hline \multirow{2}{*}{ No. } & \multirow{2}{*}{$\begin{array}{c}\text { Dimensi/ } \\
\text { Faktor kondisi sosial budaya/ } \\
\text { The dimension/Factors of } \\
\text { socio culture conditions }\end{array}$} & \multicolumn{8}{|c|}{ Kabupaten/Kota/Regencies } \\
\hline & & A & $\mathbf{B}$ & C & D & $E$ & $\mathrm{~F}$ & G & $\mathrm{H}$ \\
\hline 6 & $\begin{array}{l}\text { Sikap warga masyarakat } \\
\text { terhadap sistem gotong-royong/ } \\
\text { The society attitude to the } \\
\text { mutual assistance system }\end{array}$ & 2.0 & 2.0 & 2.0 & 1.0 & 3.0 & 3.0 & 3.0 & 3.0 \\
\hline C & HUKUM ADAT/CUSTOM ARY L & WS & & & & & & & \\
\hline 1 & $\begin{array}{l}\text { Eksistensi hukum adat sebagai } \\
\text { pengendalian sosial/ } \\
\text { The customary law existency } \\
\text { as social control }\end{array}$ & 1.0 & 1.0 & 1.0 & 2.0 & 2.0 & 1.0 & 3.0 & 3.0 \\
\hline 2 & $\begin{array}{l}\text { Kearifan masyarakat lokal } \\
\text { dalam pengelolaan sumberdaya } \\
\text { perikanan (alam)/ } \\
\text { Local wisdom in natural } \\
\text { resources management }\end{array}$ & 1.0 & 1.0 & 1.0 & 1.0 & 1.0 & 1.0 & 1.0 & 3.0 \\
\hline 3 & $\begin{array}{l}\text { Pengaturan secara adat guna } \\
\text { penyelesaian konflik/ } \\
\text { Customary management of } \\
\text { conflict resolution }\end{array}$ & 1.5 & 1.0 & 1.0 & 1.0 & 1.0 & 2.0 & 1.0 & 3.0 \\
\hline 4 & $\begin{array}{l}\text { Kejadian konflik pada } \\
\text { masyarakat nelayan tiga tahun } \\
\text { terakhir/ } \\
\text { Local conflict in last three } \\
\text { years }\end{array}$ & 3.0 & 3.0 & 3.0 & 2.5 & 2.5 & 2.0 & 1.0 & 3.0 \\
\hline D & POLITIKIPOLITICS & & & & & & & & \\
\hline 1 & $\begin{array}{l}\text { Sikap responden terhadap } \\
\text { partai politik tertentu yang ada } \\
\text { di wilayah kediaman/ } \\
\text { Respondent attitude to the } \\
\text { particular local politic party }\end{array}$ & 2.5 & 2.0 & 2.5 & 2.0 & 2.0 & 2.0 & 1.5 & 2.0 \\
\hline 2 & $\begin{array}{l}\text { Hubungan antara kekuatan- } \\
\text { kekuatan serta proses-proses } \\
\text { politik dalam sistem } \\
\text { pemerintahan/ } \\
\text { Relationship beetwen politic } \\
\text { power and process in } \\
\text { governance system }\end{array}$ & 3.0 & 3.0 & 3.0 & 2.0 & 3.0 & 3.0 & 3.0 & 3.0 \\
\hline 3 & $\begin{array}{l}\text { Peran organisasi kenelayanan } \\
\text { dalam kehidupan sosial } \\
\text { ekonomi nelayan/ } \\
\text { The function of local fishers } \\
\text { organization to the socio- } \\
\text { economic living of fishers }\end{array}$ & 2.0 & 1.0 & 1.0 & 1.0 & 1.0 & 1.0 & 1.0 & 1.0 \\
\hline
\end{tabular}


Tabel 1. Skor indikator sosial budaya masyarakat nelayan di delapan kabupaten di Indonesia, 2003 (lanjutan) Table 1. The scoring of fishers socio-culture indicator in eight regencies in Indonesia, 2003 (continued)

\begin{tabular}{|c|c|c|c|c|c|c|c|c|c|}
\hline \multirow{2}{*}{ No. } & \multirow{2}{*}{$\begin{array}{c}\text { Dimensi/ } \\
\text { Faktor kondisi sosial budaya/ } \\
\text { The dimension/Factors of } \\
\text { socio culture conditions }\end{array}$} & \multicolumn{8}{|c|}{ Kabupaten/Kota/Regencies } \\
\hline & & $\mathbf{A}$ & $\mathbf{B}$ & C & D & $\mathbf{E}$ & $\mathbf{F}$ & $\mathbf{G}$ & $\mathrm{H}$ \\
\hline 4 & $\begin{array}{l}\text { Kepemimpinan yang baik } \\
\text { menurut nelayan/ } \\
\text { The fishers perception about } \\
\text { the good leadership }\end{array}$ & 2.0 & 2.0 & 2.0 & 2.0 & 2.0 & 2.0 & 2.0 & 2.0 \\
\hline 5 & $\begin{array}{l}\text { Latar belakang sosial budaya } \\
\text { kekuatan politik / } \\
\text { The socio-culture back kround } \\
\text { of local politic strenght }\end{array}$ & 3.0 & 3.0 & 3.0 & 3.0 & 3.0 & 3.0 & 3.0 & 3.0 \\
\hline 6 & $\begin{array}{l}\text { Kekuatan politik nasional dan } \\
\text { lokal/ } \\
\text { The local and national politic } \\
\text { strenght }\end{array}$ & 3.0 & 3.0 & 3.0 & 3.0 & 3.0 & 3.0 & 3.0 & 3.0 \\
\hline E. & TINGKAH LAKU MANUSIA/HUN & $\overline{A N B E F}$ & IAVIOI & & & & & & \\
\hline 1 & $\begin{array}{l}\text { Pengertian (pendapat) } \\
\text { masyarakat nelayan tentang } \\
\text { azas-azas kehidupan/ } \\
\text { The fishers opinion about the } \\
\text { principles of life }\end{array}$ & 3.0 & 3.0 & 3.0 & 2.0 & 2.0 & 2.5 & & .0 \\
\hline 2 & $\begin{array}{l}\text { Respon terhadap pengaturan } \\
\text { sosial ekonomi jika datang dari } \\
\text { pemerintah (LSM)/ } \\
\text { The fishers respons into the } \\
\text { socio-economic management } \\
\text { that initiate by government or } \\
\text { NGO }\end{array}$ & 3.0 & 3.0 & 3.0 & 3.0 & 3.0 & 3.0 & & .0 \\
\hline 3 & $\begin{array}{l}\text { Pengertian (pendapat) } \\
\text { responden tentang perilaku dan } \\
\text { tindakan masyarakat secara } \\
\text { umum/ } \\
\text { The general opinion of } \\
\text { respondent about the society } \\
\text { behavior and action }\end{array}$ & 2.5 & 2.5 & 2.5 & 2.5 & 2.5 & 2.5 & & 2.5 \\
\hline 4 & $\begin{array}{l}\text { Ada tidaknya kejadian tentang } \\
\text { perilaku menyimpang dari } \\
\text { norma-norma yang berlaku } \\
\text { umum/ } \\
\text { The presence or absence of } \\
\text { abnormal action based on } \\
\text { general norm }\end{array}$ & 2.0 & 2.0 & 2.0 & 2.0 & 2.0 & 2.0 & & 2.0 \\
\hline Keter & $\begin{array}{ll}\text { angan/Note: } & A=\text { Medan } \\
& B=\text { Kampar } \\
& C=\text { OKI Ogan Kan } \\
& D=\text { Cirebon }\end{array}$ & ering Ilir) & & $\begin{array}{l}E= \\
F= \\
G= \\
H=\end{array}$ & $\begin{array}{l}\text { Tegal } \\
\text { Pasur } \\
\text { Bone } \\
\text { Lemb }\end{array}$ & & & & \\
\hline
\end{tabular}




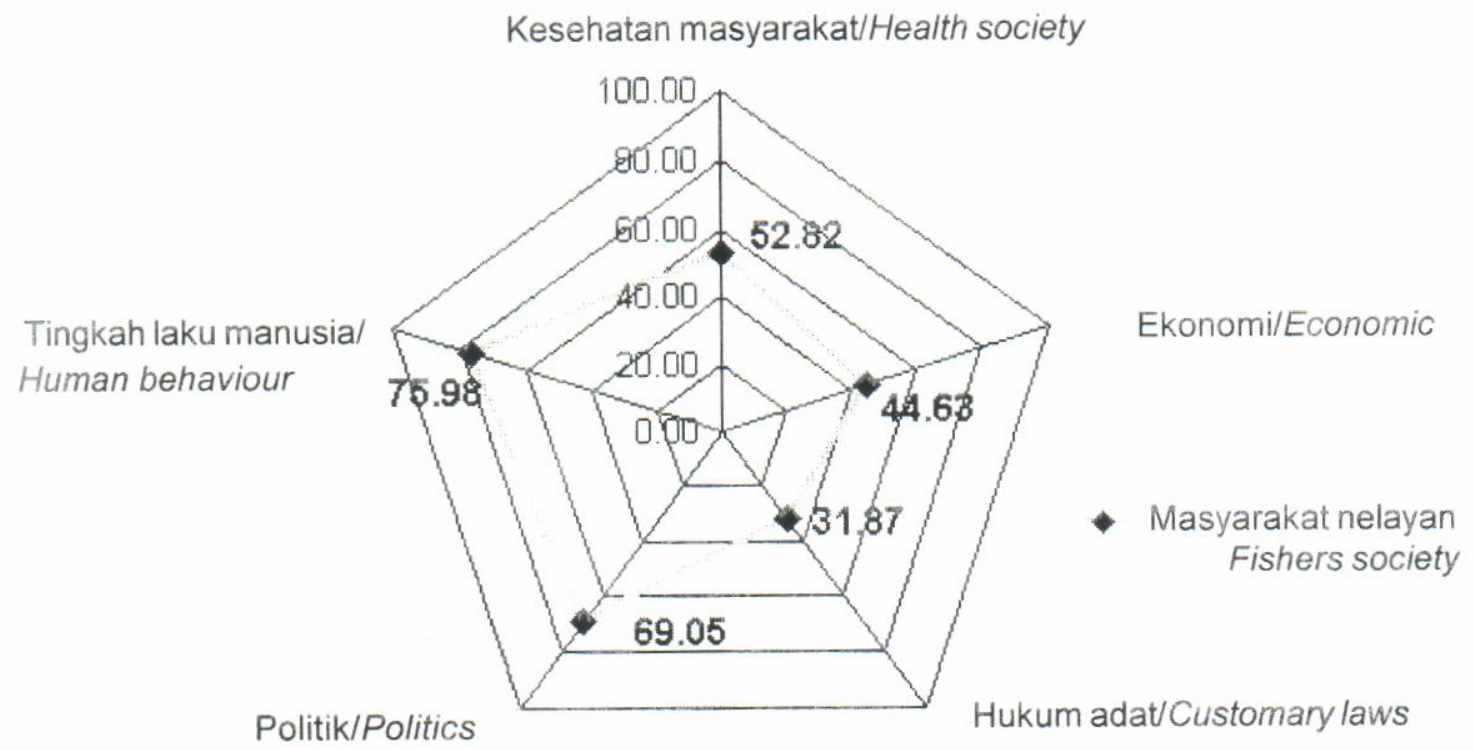

Gambar 1. Besaran relatif (skala 0-100\%) indikator sosial budaya masyarakat nelayan di delapan kabupaten, di Indonesia, 2003

Figure 1. Relative scores $(0-100 \%$ of scale) of fisherman socio-culture indicator in eight regencies, in Indonesia, 2003.

Hasil nilai kategorik dengan menyertakan pertimbangan kepakaran (expert judgement) disajikan dalam Tabel 1.

Dari diagram layang-layang pada Gambar 1 tampak besaran relatif peran setiap dimensi dibandingkan dimensi lainnya. Besaran relatif ini menunjukkan besarnya peran masing-masing dimensi sosial budaya masyarakat nelayan secara relatif dalam mendukung upaya pemberdayaan masyarakat nelayan yang bersangkutan.

Peran dimensi yang secara relatif paling kecil dibandingkan dimensi lainnya dalam mendukung upaya pemberdayaan masyarakat nelayan adalah dimensi hukum adat. Dimensi ini hanya memiliki nilai sebesar $31,87\left(R^{2}=0,95\right)$. Kecilnya nilai dimensi ini mengindikasikan peran yang kecil dalam mendukung upaya pemberdayaan masyarakat nelayan. Menilik pada sejarah hukum-hukum adat yang ada pada masyarakat nelayan di Indonesia ("sasi" di Maluku, awig-awig" di NTB dan "panglima laut" di Nangroe Aceh Darusalam), umumnya berawal dan dibentuk dari kesadaran masyarakat untuk membentuk suatu tatanan sosial, di tingkat individu atau masyarakat dengan azas distribusi hasil dan tanggung jawab yang jelas, adil dan merata, untuk menjamin keberlangsungan pemanfaatan sumberdayanya.

Dimensi ekonomi ditunjukkan dengan besaran relatif sebesar $44,63\left(R^{2}=0,92\right)$. Nilai yang relatif rendah ini, diantaranya ditunjukkan oleh langgengnya sistem patron-klien dalam kegiatan perekonomian pada sebagian besar masyarakat nelayan. Ketidakberdayaan masyarakat nelayan dalam mengakses lembaga keuangan mikro yang ada juga menjadi faktor yang dominan dalam mempengaruhi besarnya dukungan dimensi tersebut terhadap upaya pemberdayaan masyarakat nelayan. Dalam dimensi ini menjadi pegangan penting adalah cukup tingginya orientasi kerja dari masyarakat nelayan.

Dimensi kesehatan masyarakat dengan nilai sebesar $52,82\left(R^{2}=0,93\right)$ menunjukkan perlunya peningkatan di beberapa hal. Diketahui bahwa pandangan dan perilaku sebagian masyarakat yang diteliti yang sudah cukup baik dalam menyadari pentingnya kesehatan beserta upaya mereka dalam menjaga kesehatan tidak disertai dengan kemampuan mereka untuk mewujudkannya serta upaya memperbaiki sanitasi lingkungannya yang masih buruk

Dimensi dengan peran cukup besar dalam mendukung upaya pemberdayaan adalah dimensi politik dengan besaran relatif $69,05\left(R^{2}=0,93\right)$. Sementara dimensi tingkah laku menjadi dimensi yang paling berperan dalam mendukung upaya pemberdayaan dengan besaran relatif mencapai 75,98 $\left(R^{2}=0,943\right)$. Kajian dimensi untuk tingkat sosial individu ini menjadi menarik dilihat dari sudut pandang sosiologi (Berry, 2003). Dalam sosiologi, terdapat konsep yang menyatakan bahwa masyarakat sebagai 


\section{Faktor yang diungkit/Leverage of factors}

Kejadian perilaku menyimpang/ Abnormal act

Perilaku dan tindakan/ Behavior and action Pemerintah dan LSM/ Govemment and NGO

Azas kehidupan/ The Principle of Life

Politik nasional dan lokalf Local and national politic strengthens

Latar belakang sosbud politik/ Sosio culture local politic background

Kepemimpinan/ The Leadership

Organisasi kenelayanan/

Fisher organization

Kekuatan dan proses politik/ Politic power and process Sikap terhadap partai politik Attitude to local politic party Kejadian konflik/ Conflict

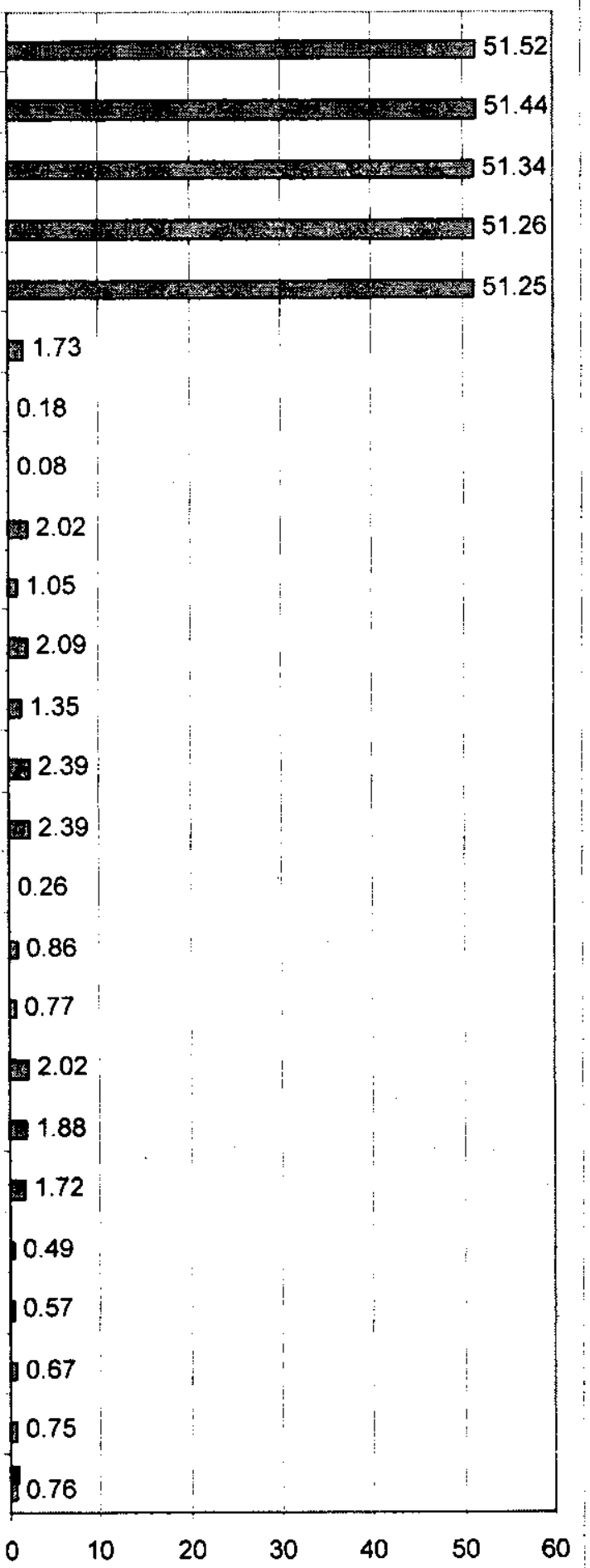

Orientasi budaya kerjal Working culture orientation

Hukum-hukum ekonomi/ Economic laws

Cara berpikir dan pandangan/ The way of thinking and perception Pengaruh sistem kemasyarakatan/ Social system influences Kebiasaan dan pantangan makan/ Behaviour and abstention Obat tradisional Traditional medicine Tentang dukun/ Scothsayer eksistance Tentang sakit/ About sick

Hidup sehat/ Healthy life

$\begin{array}{lllllll}0 & 10 & 20 & 30 & 40 & 50 & 60\end{array}$

Skala pemberdayaan (0-100)/Empowerment scale (0 to 100)

Gambar 2. Pengaruh relatif faktor determinan terhadap kondisi sosial budaya masyarakat nelayan di Indonesia, 2003.

Figure 2. The relative influence of determinant factors to fisherman socio-cultural conditions in Indonesia, 2003. 
suatu kumpulan individu yang saling berinteraksi, pada dasarnya mempengaruhi persepsi, tindakan dan perilaku seseorang atau individu yang menjadi anggotanya. Namun sebaliknya, individu sebagai anggota suatu masyarakat dianggap memiliki kekuatan tersendiri, yang seringkali sangat berpengaruh dengan karakter masyarakatnya. Oleh karena itu terkait dengan konsep pemberdayaan masyarakat yang pada hakekatnya adalah membangun sumberdaya lokal di tingkat individu dan masyarakat (Hikmat, 2001), maka diperlukan kajian lebih lanjut atas dimensi ini.

\section{Faktor Determinan}

Faktor determinan atau yang paling berperan terhadap keseluruhan indikator kondisi sosial budaya masyarakat nelayan di seluruh lokasi penelitian ditunjukkan oleh hasil uji leverage analysis. Gambar 2 menunjukkan bahwa faktor-faktor utama yang berpengaruh adalah kejadian perilaku menyimpang, perilaku dan tindakan, pemerintah dan LSM, azas kehidupan, dan politik nasional dan lokal. Dengan demikian diketahui bahwa dimensi yang berpengaruh adalah dimensi tingkah laku manusia dan dimensi politik. Kedua dimensi tersebut memiliki besaran relatif pengaruh sebesar 51,25 hingga 51,52 , sangat menonjol jika dibandingkan dengan faktor-faktor lainnya dengan besaran relatif pengaruh berkisar 0,08 hingga 2,39 .

Kemungkinan yang terjadi dari hasil ini adalah faktor-faktor lain merupakan faktor ikutan dari faktor determinan. Dengan asumsi ini, jika faktor determinan diberdayakan dan atau diperbaiki maka faktor-faktor lain akan turut terpengaruh menjadi berdaya atau menjadi baik.

\section{Keterandaian Indikator Penjelas Sosial Budaya}

Keterandalan (reliabilitas) faktor-faktor sebagai penjelas indikator kondisi sosial budaya dalam kaitannya dengan pemberdayaan masyarakat nelayan diketahui berdasarkan kajian lebih lanjut

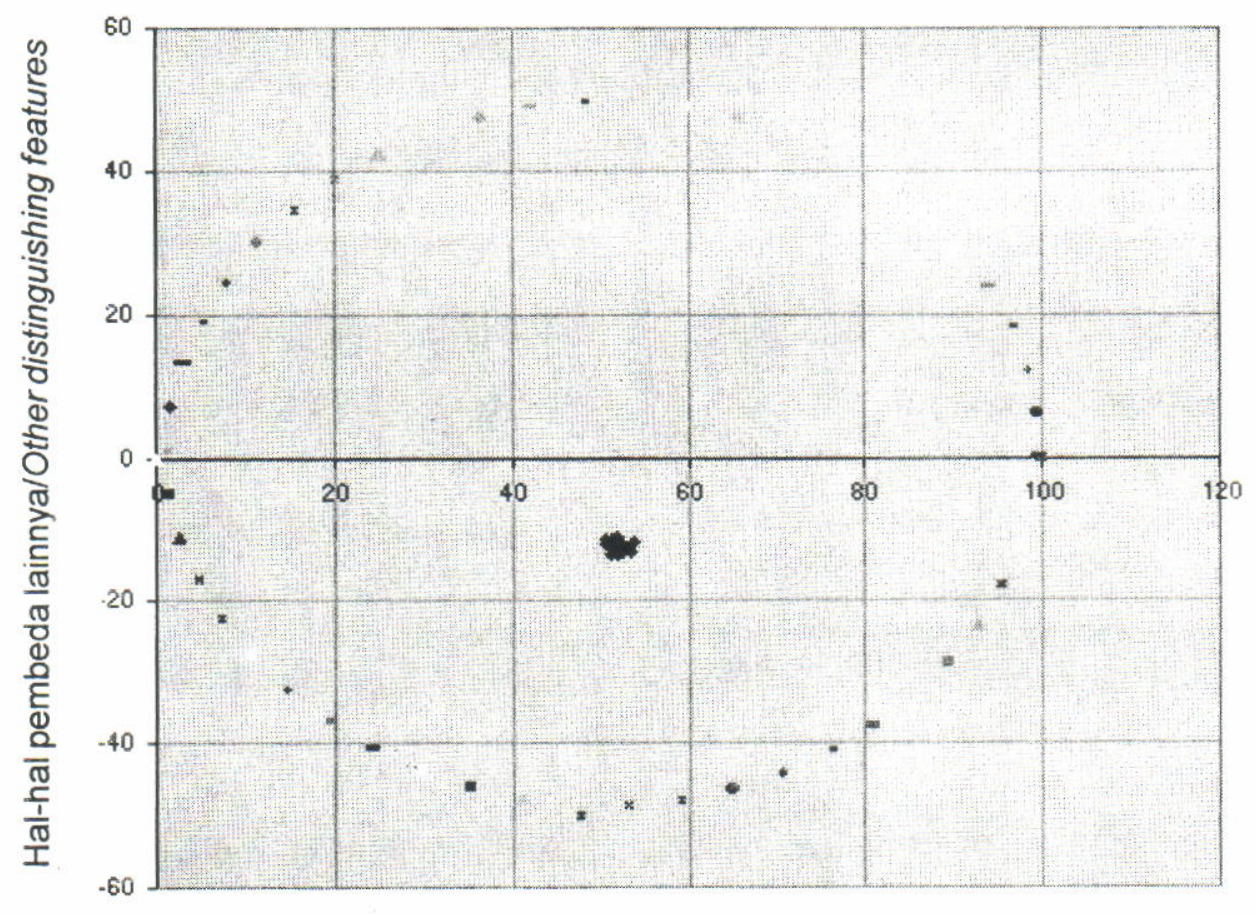

Pemberdayaan masyarakat/Community empowerment

Gambar 3. Diagram pencar analisis Monte Carlo terhadap faktor determinan kondisi sosial budaya dalam pemberdayaan masyarakat nelayan di Indonesia, 2003

Figure 3. Monte Carlo analysis scatter plot of determinant factor of socio-culture conditions due to the fishers empowerment in Indonesia, 2003. 
terhadap hasil pengujian ordinasi nilai-nilai faktor untuk keseluruhan dimensi (indikator kondisi) pada analisis skala multi dimensi. Program RAPFISH digunakan dalam analisis skala multi dimensi dengan fasilitasi analisis Monte Carlo.

Analisis Monte Carto digunakan untuk mengetahui apakah faktor-faktor yang ada cukup handal (reliable) sebagai penjelas indikator kondisi sosial budaya secara keseluruhan. Dengan demikian dapat diketahui sejauh mana aspek ketidak-pastian dan anomali dari faktor yang dianalisis dapat ditolerir. Anomali dari faktor yang dianalisis adalah apabila sebaran dari nilai analisis Monte Carlo (iterasi 20 kali) berada di luar kisaran normal nilai pembatas (anchors) (Pitcher \& Preikshot, 2001).

Pada Gambar 3 terihat seluruh faktor yang dianalisis di setiap dimensi berada di dalam kisaran normal yang ditunjukkan oleh masing-masing nilai pembatasannya (anchorsnya). Hal ini menunjukkan pula nilai dari faktor-faktor yang dianalisis telah menyebar normal. Sementara itu yang dimaksud dengan ketidak-pastian dari faktor yang dianalisis dalam analisis Monte Carlo adalah posisi relatif antar setiap nilai faktor hasil iterasi.

Kecenderungan nilai iterasi faktor-faktor yang semakin mengelompok menunjukkan bahwa faktorfaktor tersebut semakin homogen (baik) sebagai penjelas indikator kondisi, sebaliknya apabila kecenderungannya semakin menyebar (berada di luar ordinasi) menunjukkan adanya ketidak sesuaian (tidak reliabel) sebagai faktor penjelas suatu indikator kondisi.

Disamping itu besaran ketidak-pastian secara relatif dapat ditunjukkan oleh jarak kelompok nilai iterasi faktor-faktor dengan sumbu horizontal (sumbu skala good-bad). Semakin jauh (baik ke arah positif ataupun negatif) menunjukkan adanya faktor-faktor lain yang pada prinsipnya belum disertakan untuk dijadikan faktor di dalam menunjukkan dimensi atau indikator kondisi yang bersangkutan. Hasil analisis Monte Carlo untuk indikator kondisi sosial budaya, menunjukkan adanya kecenderungan faktor-faktor tersebut yang handal (reliable) untuk difungsikan sebagai penjelas indikator kondisi sosial budaya dalam kaitannya dengan pemberdayaan masyarakat nelayan (Gambar 3).

\section{KESIMPULAN DAN SARAN}

Indikator kondisi sosial budaya masyarakat nelayan menunjukkan besaran relatif peranan dimensi tingkah laku sebesar 75,98\%; dimensi politik 69,05\%; dimensi kesehatan masyarakat $52,82 \%$; dimensi ekonomi 44,63\%; dan dimensi hukum adat $31,87 \%$. Tingginya nilai ini memberikan indikasi bahwa dimensi tersebut lebih berperanan dalam mendukung keberhasilan upaya pemberdayaan masyarakat nelayan.

Dimensi determinan adalah dimensi tingkah laku manusia dan dimensi politik, sedangkan faktor determinan adalah kejadian perilaku menyimpang, perilaku dan tindakan, pemerintah dan LSM, azas kehidupan, dan politik nasional dan lokal. Besaran relatif faktor determinan tersebut berkisar 51,25 hingga 51,52, sedangkan peranan faktor lainnya besaran relatifnya hanya bernilai 0,08 hingga 2,39. Berdasarkan hasil pengujian ordinasi nilai-nilai faktor untuk keseluruhan dimensi (indikator kondisi) pada analisis Multi Dimensional Scaling (MDS) menunjukkan bahwa secara keseluruhan faktorfaktor tersebut cukup handal (reliable) difungsikan sebagai penjelas indikator kondisi sosial budaya dalam kaitannya dengan pemberdayaan masyarakat nelayan.

Dalam konteks program utama penguatan kelembagaan masyarakat nelayan, rendahnya peran dimensi hukum adat dan ekonomi merupakan indikasi lemahnya kelembagaan sosial budaya masyarakat nelayan. Berdasarkan konsep pemberdayaan maka seyogyanya masyarakat harus dapat mengoptimalkan pemanfaatan sumberdayanya. Salah satu sumberdaya tersebut berupa modal sosial dalam bentuk kelembagaan sosial dan ekonomi. Dengan hadir dan kuatnya kelembagaan masyarakat nelayan di kedua bidang kehidupan tersebut, maka diharapkan akan mendukung tumbuh dan hidupnya suatu sistem masyarakat nelayan mandiri.

Program pendukung penguatan kelembagaan masyarakat nelayan mencakup: (a) Program penambahan atau perbaikan infrastruktur sosial di bidang kesehatan; (b) Program sosialisasi dan penyuluhan di bidang sanitasi lingkungan; dan (c) Program penyuluhan dan penerapan teknologi tepat guna. Dominansi program penyuluhan sebagai program pendukung dikarenakan menonjolnya pengaruh faktor-faktor dan besarnya peranan dimensi tingkah laku dalam masyarakat. Hal ini tampak dari kendalakendala upaya pemberdayaan masyarakat nelayan selama ini bersumber dari aspek sosial-budaya dalam masyarakat. Diantaranya berupa kurangnya kesadaran masyarakat tentang urgensi program dan masih banyaknya masyarakat yang menilai program pemerintah merupakan "bantuan", sehingga dana yang disalurkan terkait dengan kegiatan pemberdayaan masyarakat tidak perlu dikembalikan.

\section{DAFTAR PUSTAKA}

Berry, D. 2003. Pokok-pokok Pikiran Sosiologi. PT. Raja Grafindo Persada. Jakarta. 279 pp. 
Cernea, M.M., 1988. Sosiologi Untuk Proyek-Proyek Pembangunan. dalam Cernea, M.M. (ed.). Mengutamakan Manusia Dalam Pembangunan; Variabel-Variabel Sosiologi di dalam Pembangunan Pedesaan. Publikasi Bank Dunia. Penerjemah; B.B. Teku. Universitas Indonesia Press. Jakarta. p. 3-26.

Hikmat, R. 2001. Strategi Pemberdayaan Masyarakat. Humaniora Utama Press. Bandung. Cetakan Pertama. $260 \mathrm{pp}$.

Koentjaraningrat. 1990. Pengantar IImu Antropologi. Penerbit Rineka Cipta. Bandung. 391 pp.

Nasution, Z., dkk, 2004. Riset Sosio Antropologi Dalam Rangka Pemberdayaan Masyarakat Nelayan, Laporan Teknis. Bagian Proyek Riset Pengolahan Produk dan Sosial Ekonomi Kelautan dan Perikanan. PRPPSE, BRKP. Jakarta.
Pitcher, T.J. and Preikshot, D. 2001. RAPFISH: A Rapid Appraisal Technique to Evaluate the Sustainability Status of Fisheries. Fisheries Research. 49(3): 255 270. Fisheries Center University of British Columbia. Vancouver

Soekanto, S. 2003. Sosiologi: Suatu Pengantar. PT. Raja Grafindo Persada. Jakarta. 466 pp.

Wahyono, A., Antariksa, I.G.P., Imron, M., Indrawasih, R. dan Sudiyono. 2001. Pemberdayaan Masyarakat Nelayan. Penerbit Media Pressindo bekerjasama dengan Yayasan Adikarya IKAPI dan Ford Foundation. Cetakan Pertama. Jakarta. 226 pp.

Welcomme, R.L. 1985. River Fisheries. Food and Agriculture Organization Fisheries Technical Paper, (262) : 330 . 


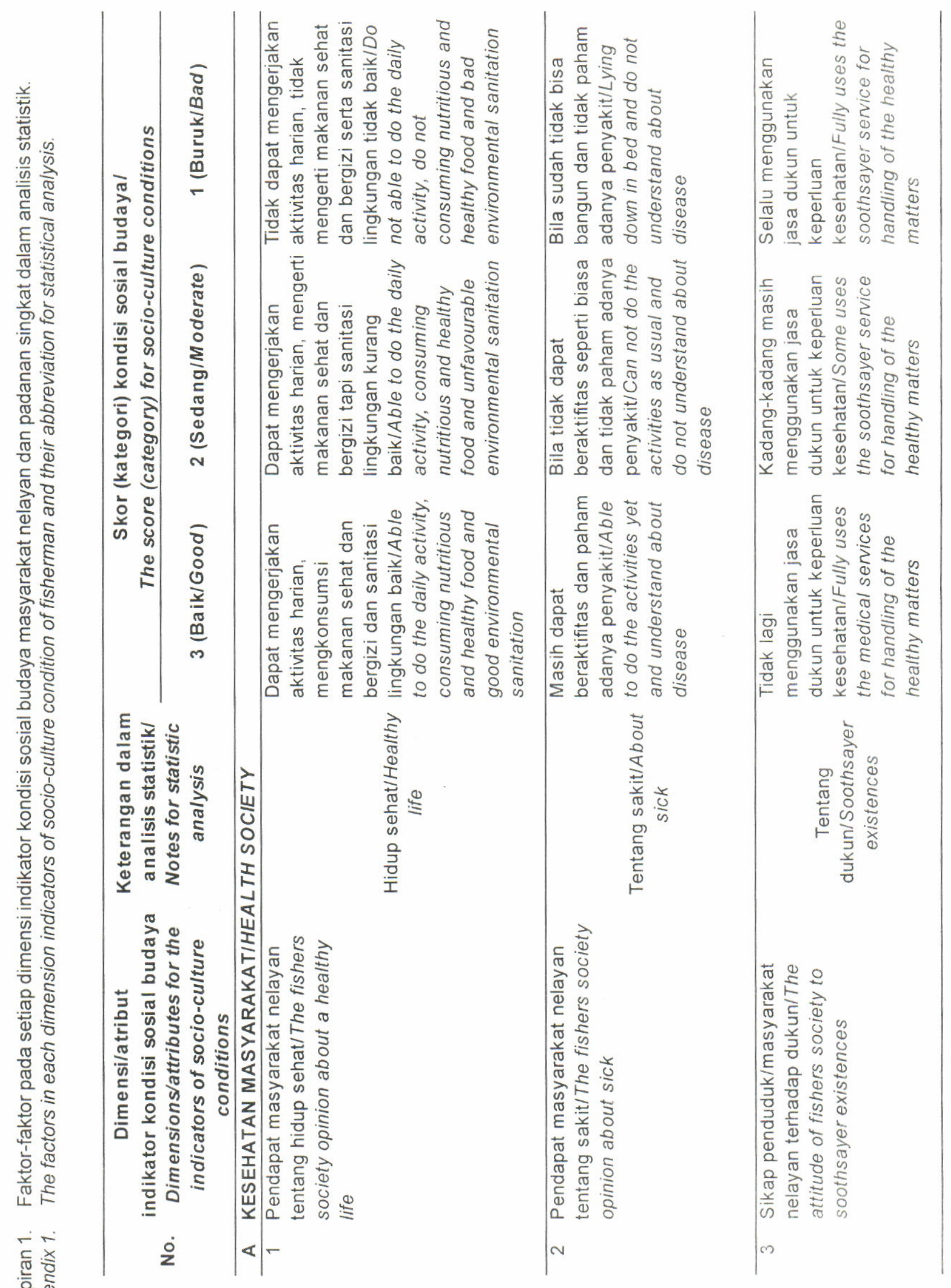




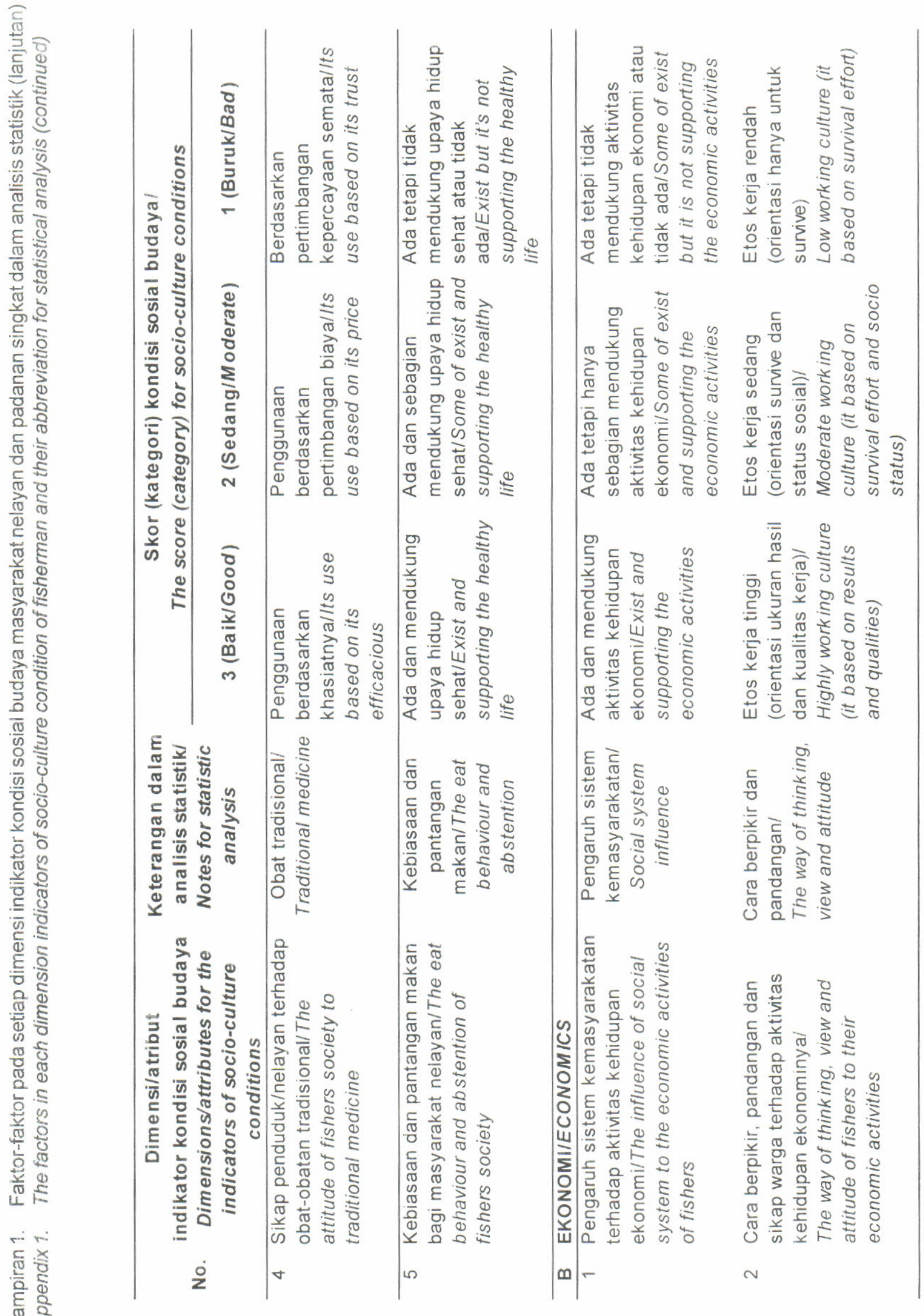




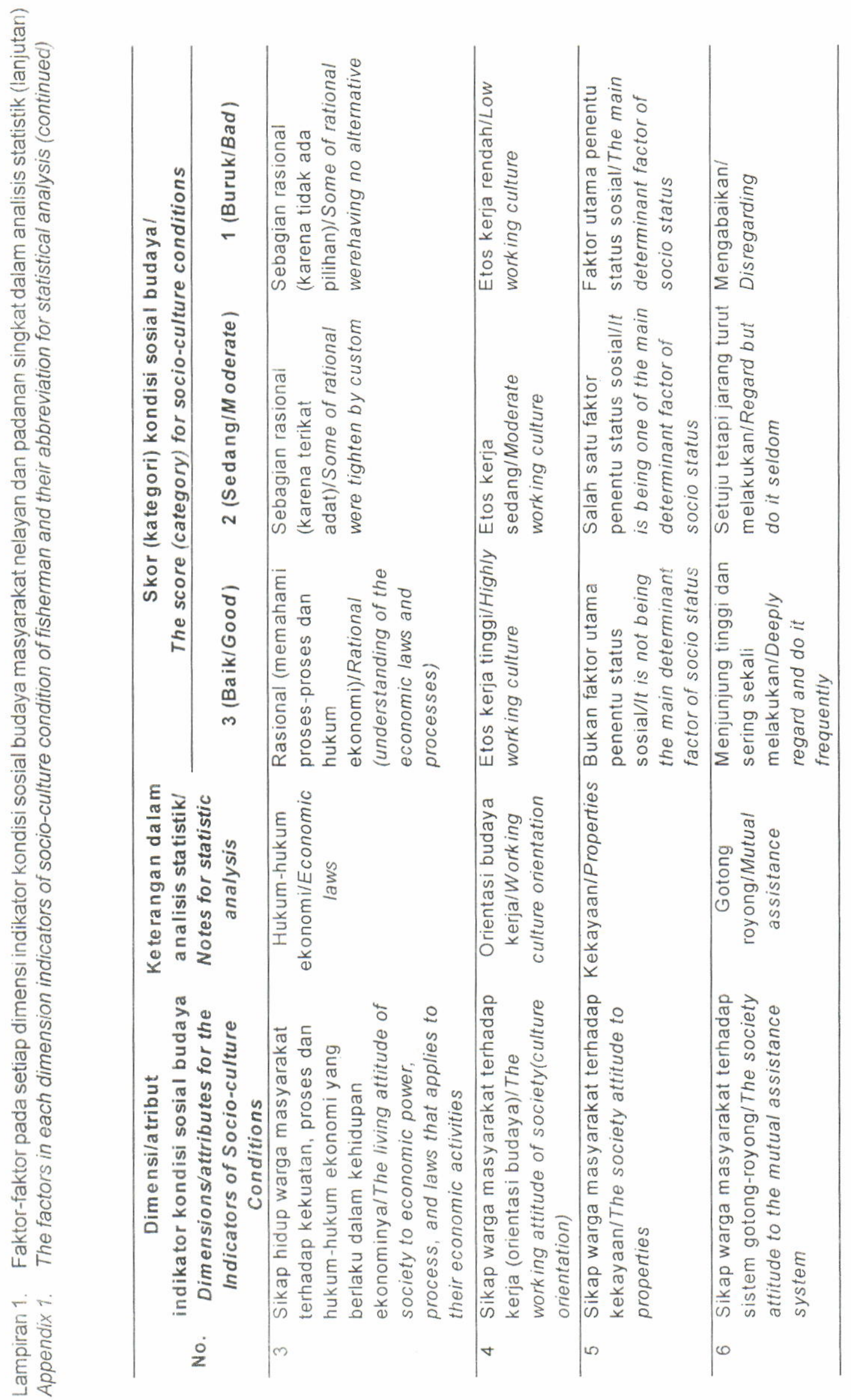




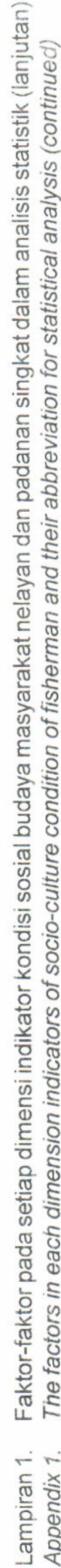

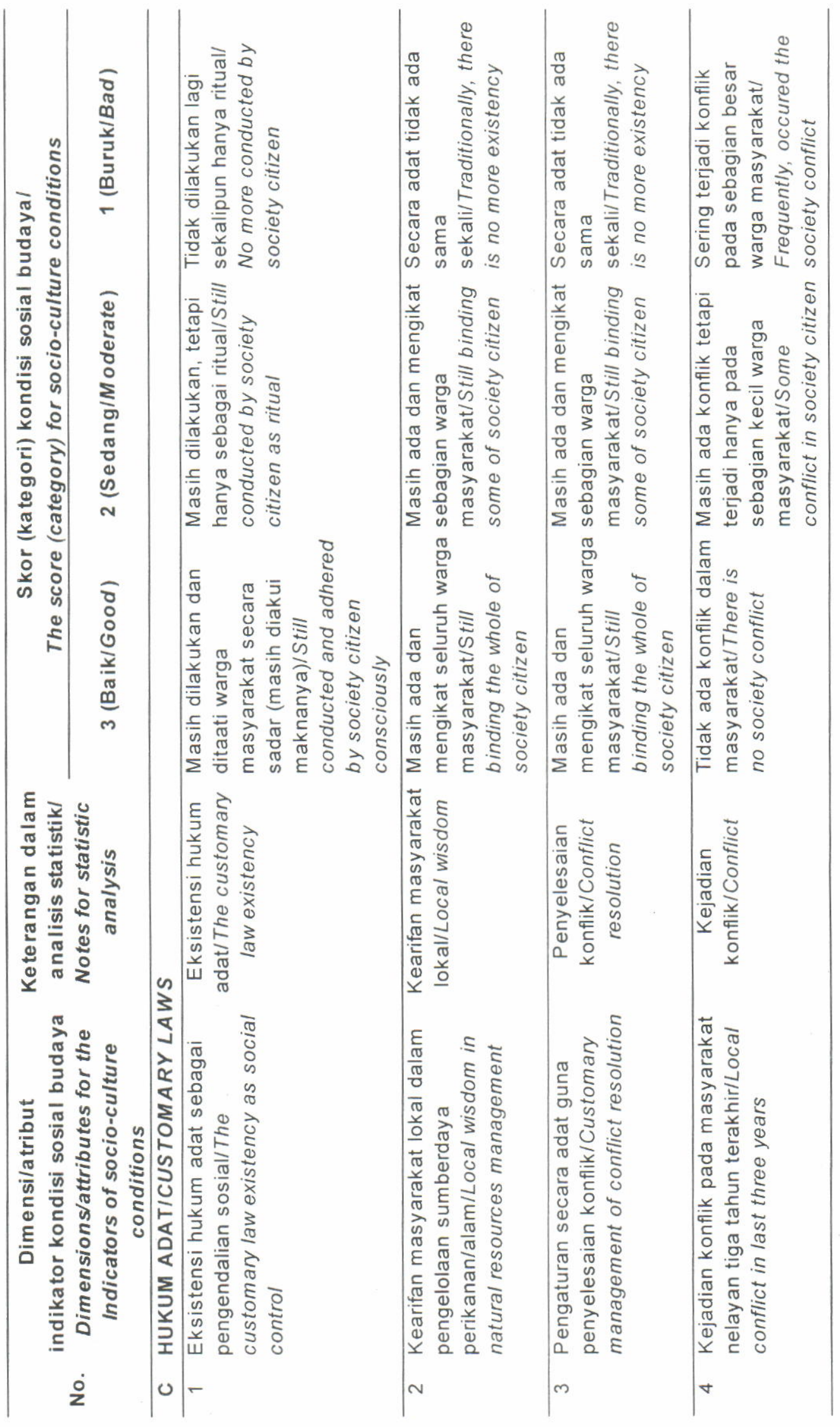




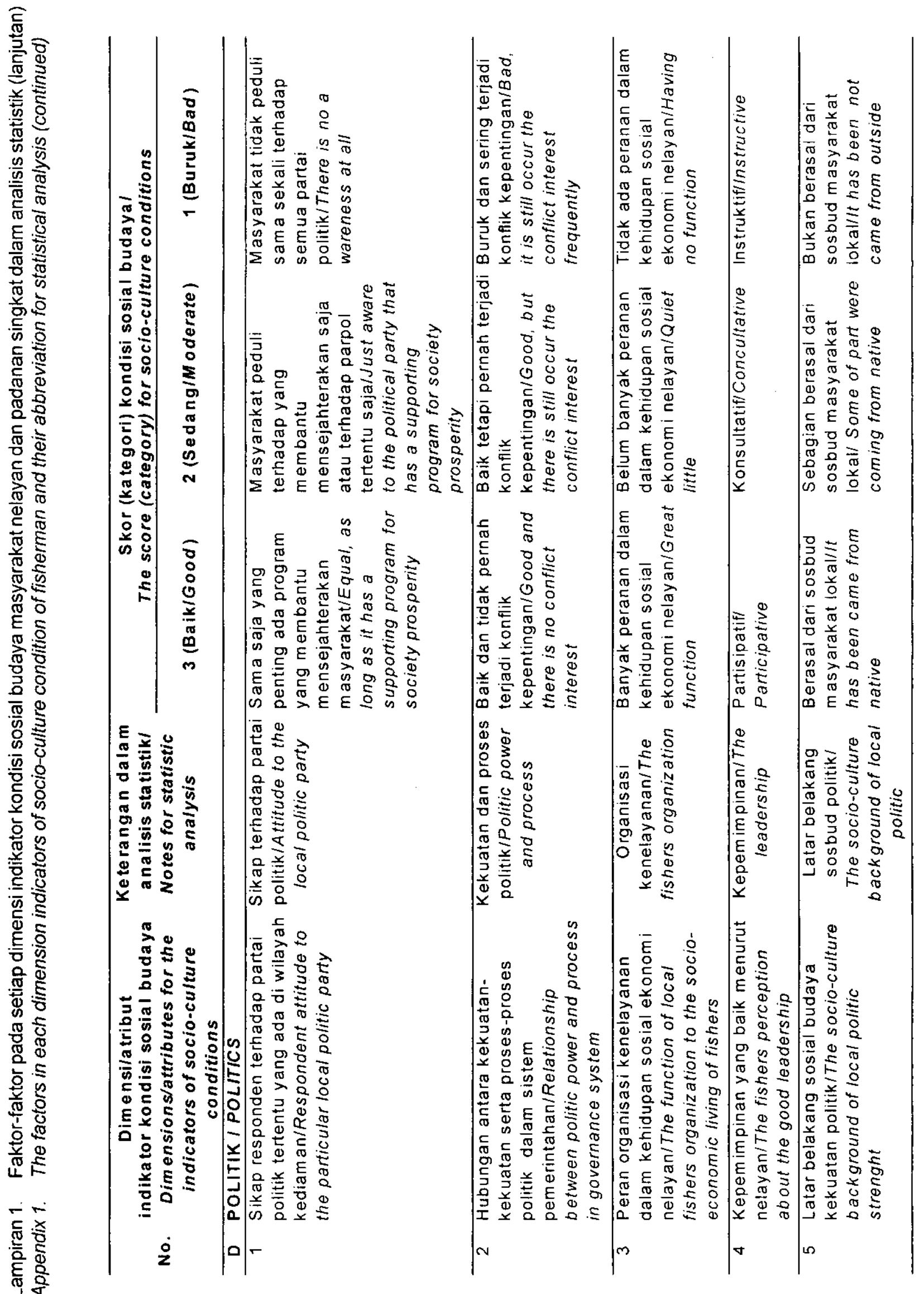




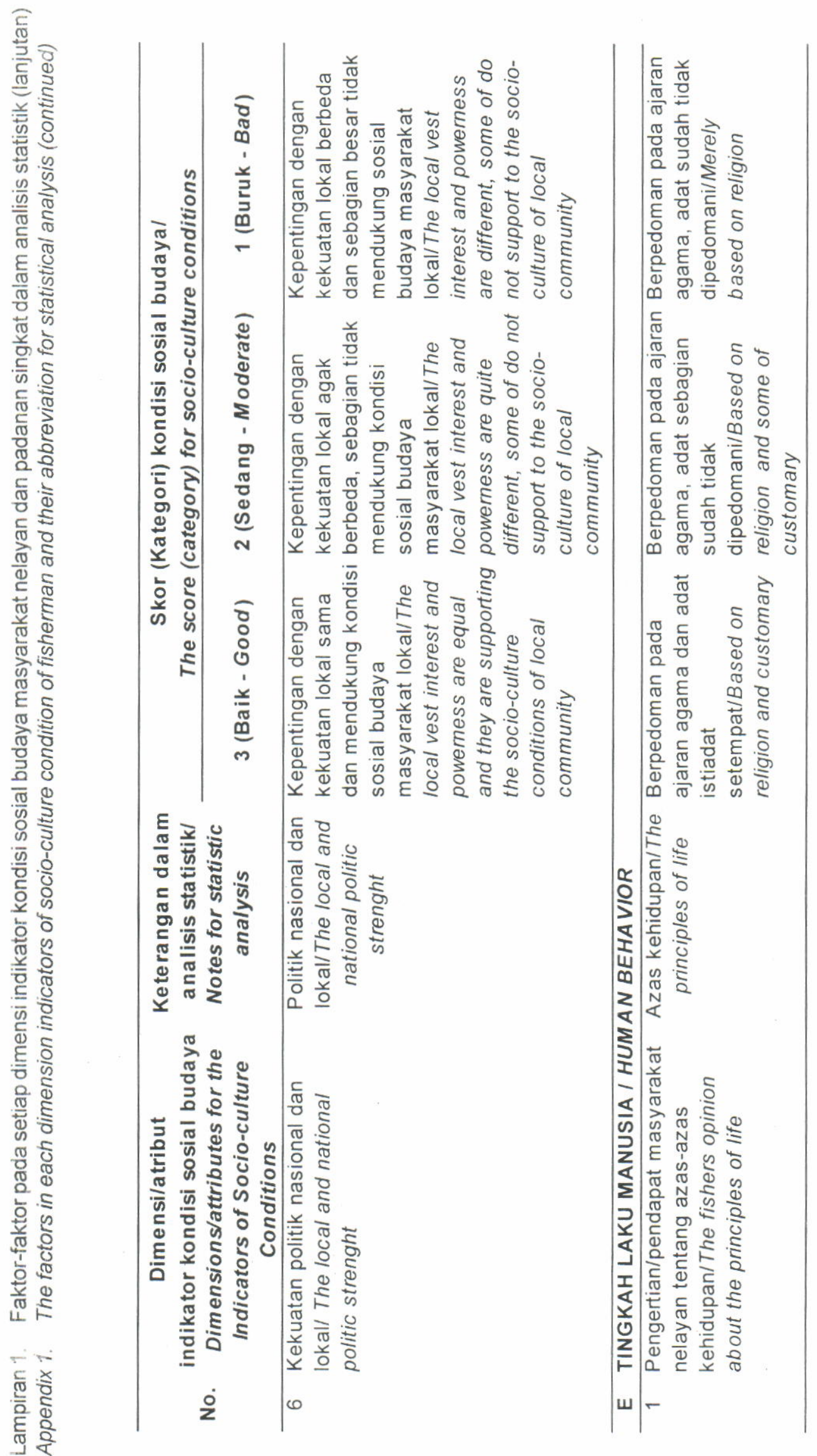




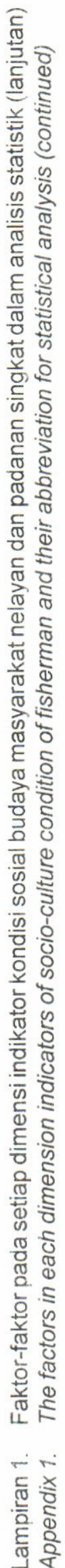

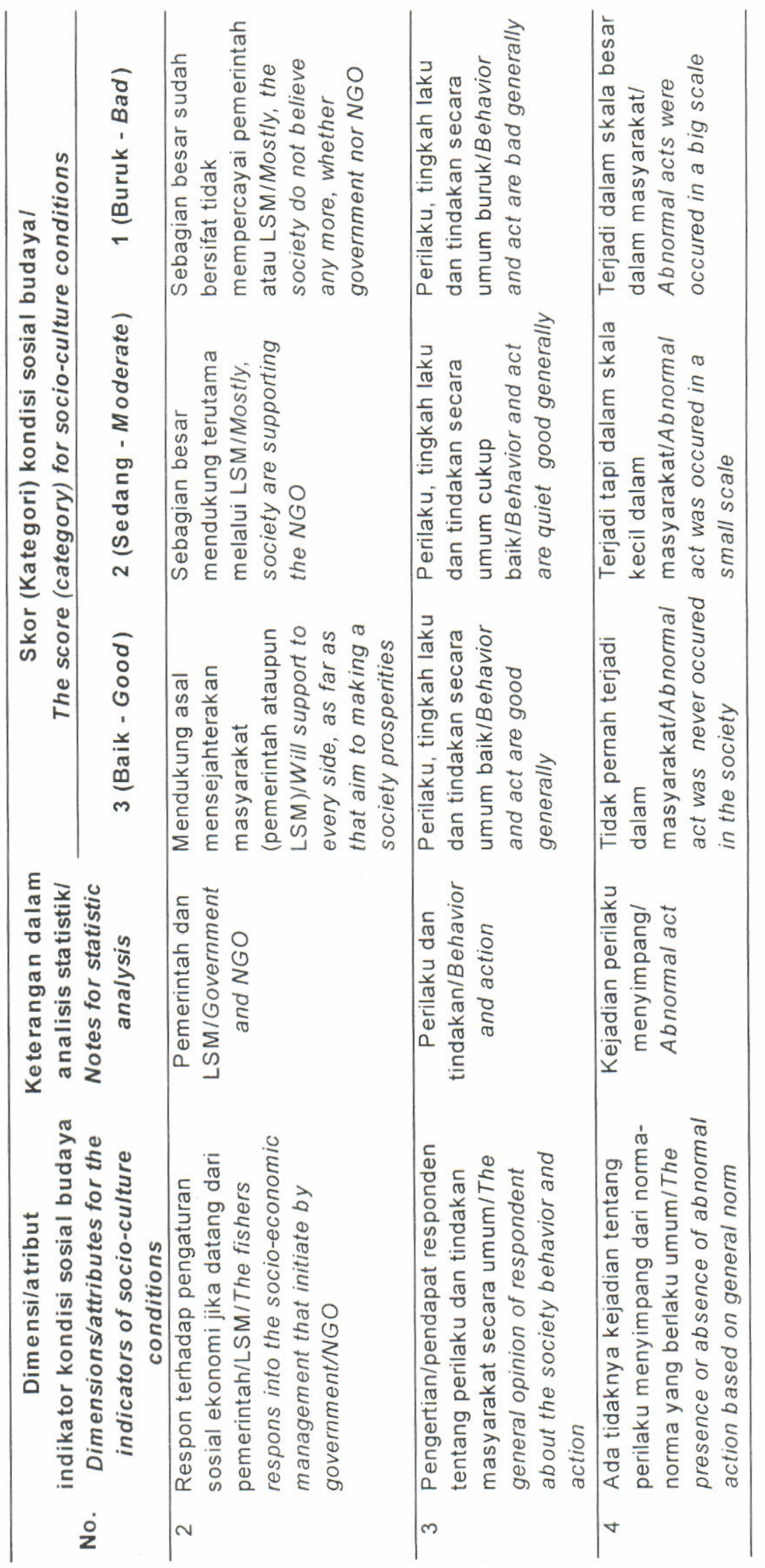


